\title{
Research on the Energy Saving and Emission Reduction Path of Transporting Ships
}

\author{
Hongbin Wei* \\ China Waterborne Transport Research Institute, Beijing, China \\ ${ }^{*}$ Corresponding author
}

\begin{abstract}
As an important means of water transportation, ships bear domestic and international trade and transportation, and consume a large amount of fuel every year. It is imperative to improve ship energy efficiency and reduce energy consumption. Describes the international situation of ship energy save and emission reduction, to divide the development course of international standards. The constraint index form, listing the coping styles adopted by Chinese government, that the shipbuilding industry in the formulation of standards and norms constraint index. This paper discusses the factors affecting the energy save and emission reduction, including marine technology, transport capacity and energy consumption, ship operations management, manage system, and explore the path to improve transport ship during operation.
\end{abstract}

Keywords-energy save and emission reduction; international standards; constraint index; marine technology; constraint index; transport capacity and energy consumption; ship operations management; manage system

\section{INTRODUCTION}

After the entry into force of the MARPOL Rules for the Prevention of Air Pollution by MARO (MARPOL73 / 78 Annex VI) published by the International Maritime Organization (IMO) in 2005,shipping has been incorporated into the energy conservation, which has a positive significance of the environmental protection.

As the largest carrying capacity of transport in the transport vehicle, the current ocean-going vessels a total of about 80,000 , bear the world trade $97 \%$ of the traffic, the annual consumption of hundreds of millions of tons of oil fuel.

Scientific and technological progress force companies to technological innovation. The world's major shipping companies are faced with global trade volume reduction, income reduction, fuel prices, the cost of a substantial increase in the plight of the World Trade Organization, but also to deal with the new energy-saving emission reduction regulations.

Some large shipping companies in response to this "green revolution", have invested a lot of manpower, material and financial resources, research, digest and absorb the world's leading energy-saving environmental protection technology.

Technical progress and economic development, to promote the ship energy-saving emission reduction technology standards gradually improve the selection of constraints more reasonable. In order to reduce the energy consumption of the ship and improve the energy efficiency of the ship, the paper discusses the path of improving the energy efficiency of the ship during the operation of the ship.

\section{CONVENTION STANDARDS BECOME HARSH}

IMO began to prevent air pollution from ships beginning in 1990s. At the conference on International Convention against pollution caused by ships, held in 1997, IMO adopted the rules on the prevention of air pollution from ships, which marked the beginning of IMO's legislation on air pollution prevention by ships. At the forty second meeting of the Marine Environment Protection Committee (MEPC) held in 1998, the committee adopted recommendations for a closer study of the issue of $\mathrm{CO}_{2}$ emissions from ships, and established the steering committee on projects. The findings were presented at the MEPC45 conference held in 2000. The report entitled IMO ship on greenhouse gas emissions, the report shows that the marine is a kind of clean, green and environmentally friendly mode of transport, and the energy efficiency is high; its greenhouse gas emissions accounted for only $1.8 \%$ of total global emissions; compared with the others way of transporting the goods, shipping is the emission of $\mathrm{CO}_{2}$ the least among of transportation.

The developing and developed countries debate on the "common but differentiated responsibilities", because of whether the developing countries and the developed countries bear the same ship emissions limits; so as to achieve the "no difference" principle has been plagued by ships IMO emission reduction legislation. At the forty eighth meeting of the MEPC, Chinese representatives of the Jin Dong "Protocol" requirements, the IMO should consider shipping greenhouse gas emissions of international navigation problems, but its national scope should be limited to the United Nations Framework Convention on climate change "Kyoto Protocol" annex I countries. The "Kyoto Protocol" in Annex I countries only in developed countries, they promised to limit and reduce greenhouse gas emissions obligations and responsibilities, developing countries do not undertake any obligation to limit and reduce greenhouse gas emissions from ships.

In 2005, at the fifty third meeting of the MEPC, the guidelines for the provisional pilot guidelines on voluntary testing of the $\mathrm{CO}_{2}$ emission index of ships were issued to enable vessel operators to assess the performance of their ships in terms of $\mathrm{CO}_{2}$ emissions. Since the emissions of $\mathrm{CO}_{2}$ are directly related to the consumption of marine fuels, the $\mathrm{CO}_{2}$ index will also provide useful information on the fuel 
efficiency of ships. In 2009, it approved the new vessel energy efficiency design index (EEDI) which is technical energy save emission reduction and marine energy efficiency management plan (SEEMP) which is a letter of operation on energy save and emission reduction. At its fifty ninth meeting, MEPC adopted four interim guidelines, including EEDI calculation methods and certification, SEEMP formulation and application. The adoption of EEDI enables the newly built ships to calculate the energy efficiency design index according to the formula recommended by the guidelines, thus reflecting the energy efficiency of the newly built ships. The adoption of SEEMP provides guidance for the selection of appropriate means of emission reduction and the formulation of energy efficiency management plans for ships and shipping companies, as well as the evaluation of their energy efficiency operations based on the energy efficiency index. It is important to note that the four criteria used in the three criteria are "voluntary, provisional and probationary", and the guidelines are at the trial stage.

Until 2011, after the rule is explored during the period of two years, through amendments to MARPOL annex VI at the sixty second MEPC meeting, the fourth chapter "new ship energy efficiency rules", through the "new ship design energy efficiency index" and "ship energy efficiency management plan" two ship energy efficiency standards, and in effective January 1, 2013. The 2012 meeting of the sixty-third session of the MEPC through EEDI and SEEMP important guidelines on the implementation of mandatory energy efficiency measures, and to determine the 2013 on tonnage of more than 400 tons in all shipping merchant force, two standards are implemented on 2015.

\section{CONSTRAINT INDICATORS TO COPE WITH}

In order to cope with the global climate change and the restrictions imposed by the international conventions on China, the Chinese government has adopted a method of gradually decomposing the tasks of energy conservation and emission reduction in China to formulate overall energy conservation and emission reduction targets. The Chinese government has formulated the "12th Five-Year" planning period to reduce energy consumption and emissions reduction targets, the index is divided into four aspects, including carbon dioxide emissions per unit of GDP, non-fossil energy in primary energy consumption, the total emissions of major pollutants and GDP energy consumption unit.

In order to ensure the realization of the planning goal, the Chinese government adopts the way of energy conservation and emission reduction in accordance with the law, and revised and promulgated relevant laws on energy conservation and emission reduction. The Standing Committee of the National People's Congress has revised and adopted the new energy conservation law, which shall come into force as of April 1, 2008. The energy conservation law of the People's Republic of China stipulates clearly that conserving resources is the basic state policy of our country. The State implements the strategy of energy conservation with development and the strategy of saving energy in the first place. At the same time, the relevant departments of the State Council shall formulate standards for the limits of fuel consumption for transport vehicles and vessels, which are not up to standard and shall not be used for operation.

The Ministry of finance, the State Administration of Taxation and the Ministry of industry and Commerce jointly issued the catalogue of models for saving energy and using new energy vehicles to reduce vehicle and vessel tax, and clearly defined policies concerning the reduction of energy and the use of new energy sources and the reduction of vehicle and vessel tax. The Ministry of Finance and the Ministry of transportation jointly issued the "Interim Measures" transportation special funds for energy conservation and management, clear funds to support the transport of energy save and emission reduction, the principle of the use of special funds to take the way of substituting subsidies with rewards, by the Ministry of finance, the Ministry of transport according to the comprehensive measure of the nature of the project, the total amount of investment, the actual energy save and emission reduction the amount and the social benefit to determine the amount of subsidies.

\section{TeChNicAl Aspects of SHIPS}

Technical efficiency: by strengthening the scientific and technological progress and innovation of ship in the field of energy conservation, and actively promote the application of modern ship energy save equipment and technology, organization related to ship energy save products and technology promotion, improve turnover efficiency of shipping and ship transport energy level. One part is the use of energy save technology in the ship, in order to reduce the ship resistance, improve the propulsion efficiency, optimization design and structure of the hull propeller and stern flow recovery energy, the other part is the use of energy save technology in ship or in equipment.

Technical factors: affecting the energy efficiency of waterway transportation, including ship design and manufacturing technology, new technologies for marine energy conservation and new marine energy save products.

\section{A. Research and Develop New Ships}

$\mathrm{R} \& \mathrm{D}$ to promote energy save emission reduction of new transport ships. The development of new technology of ship energy save, development and adoption of new energy save type and advanced power system, improve the level of ship design and manufacture to encourage the use of new technologies, new materials, new technology and new structure, actively optimize the new ship and its main scale line optimization design to reduce the ship weight, selecting advanced propeller, low speed and large diameter propeller, the such type of diesel engine, improve fuel efficiency.

\section{B. Research and Develop New Technologies and Products}

$\mathrm{R} \& \mathrm{D}$ to promote energy save new technologies, new products. The development of matching energy save technology, optimization of ship operation parameters, actively develop and utilize additional thrust fins to improve rudder effect, reduce the resistance; encourage the promotion and application of advanced and applicable energy save technologies (products), such as the use of new energy save 
emission reduction technology of national demonstration promotion, lower level of ship energy consumption; exhaust gas waste heat recovery application the use of energy save technology, host diffuser and shaft generator main engine exhaust pipe, reduce the ship auxiliary energy levels.

\section{Structural AsPects OF SHIPS}

Structural energy save aspects: through government macro-control and actively planning, and promote inland shipping transportation structure adjustment, optimization of ship capacity structure, improve the energy consumption structure, improve the overall energy level of water transport ship system. Optimize the tonnage structure of the fleet, develop large-scale and standardized ships adapted to the technical standards of the channel, and promote the development of large-scale and specialized marine shipping.

Structural factors: affecting the energy efficiency of waterway transportation, including the structure of shipping capacity and the structure of energy consumption.

Structural energy save and emission reduction measures, optimizing the tonnage structure of ships, developing largescale and standardized ships adapted to the technical standards of waterways, and promoting the development of large-scale and specialized shipping ships.

\section{A. Optimize the Structure of Ship Capacity}

Speed up the adjustment of marine transport capacity structure. Optimizes the tonnage structure of the fleet, promote the development of large-scale and specialized marine ships, and speed up the fleet with appropriate scale. Promote the adjustment of inland waterway transport capacity structure. Promote the application of energy save and environmentally friendly transport ship type, speed up the elimination of high energy consumption, low efficiency of old operating transport ships, and guide the operation of ships to large-scale, professional, standardized and low-carbon direction. Development of large-scale and standardized ships adapted to the technical standards of waterways. Actively guide the establishment of professional transport enterprises and format inland transport fleet, improve the ship tonnage, the development of large-scale transportation, and reduce fuel consumption.

\section{B. Optimize the Energy Consumption Structure of Ships}

Promote the optimization of energy consumption structure of transportation, and encourage the application of alternative energy sources in operating ships. Promote the development of the new type of marine fuels, moderate in the ship fuel cell, promote the use of solar energy, bio diesel, liquefied natural gas (LNG), liquefied petroleum gas (LPG) and other clean energy, promote the use of shore power, wind driven technology.

\section{OPERATion Management AsPects OF SHIPS}

The management of energy by strengthening the transportation organization management, supervision and management of energy save management, enhance the efficiency, strengthen traffic market supervision, improve the transportation market system, and constantly improve the traffic system operation efficiency and management level of transportation organization. Summarize the advanced management experience of shipping enterprises and ship owners; seek the advanced and scientific management models of energy save and emission reduction, and increase management during operation.

Management factors: affecting the energy efficiency of waterway transportation, mainly including speed management, ship carrying capacity utilization, shipping logistics organization and auxiliary energy management.

Management measures for energy save and emission reduction, summarizes the advanced management experience of shipping, shipping enterprises and ship-owners, and seeks advanced and scientific energy save emission reduction management mode to increase management in the operation process.

\section{A. Enhance the Level of Energy Efficiency}

Improve standards, policies and regulations of energy save system, through the establishment of a new ship energy save design specification, evaluation system and technical standards, regulations to be invested ship operation market, divided into different types of ships and shipping areas, including second-hand ship shipbuilding, from the international market and to purchase foreign ships bareboat lease conditions, recommended fuel consumption limits and $\mathrm{CO} 2$ emission limits, the establishment of the operation of the ship market access standard.

In 2012, the operating ship fuel consumption limits and methods of verification and the operating ship CO2 emission limits and verification methods were published. Two measures recommended fuel consumption limits and CO2 emission limits (with different types of ships and shipping areas), emission index calculation and verification methods, measures for domestic ships, with diesel engines as the main propulsion, 400 gross tons and above the dry bulk ships, container ships and oil ship. Multi-purpose ships are carried out in reference to dry bulk carriers; they are not applicable to ships propelled by diesel electric propulsion, turbine propulsion and hybrid propulsion systems.

\section{B. Improving Energy Efficiency}

Establish energy save performance evaluation and assessment system, formulate policies to encourage and encourage energy conservation and emission reduction, and form a long-term energy save mechanism to ensure the development of a resource-saving and environment-friendly shipping. Support for enterprises and institutions to carry out highway waterway transportation, energy save and emission reduction work, support and promote the development and application of the promotion and application of energy save and emission reduction of transportation industry new mechanism, new technology, and new products. 


\section{INSTITUTIONAL ASPECTS OF SHIPS}

Through the improvement of the ship energy save regulations and standards, the introduction of market mechanism, construction of the ship energy save entry and exit mechanism, the establishment of the shipbuilding industry overall energy save emission reduction mechanism, which take energy save emission reduction guide and mandatory measures to follow. We will formulate policies for encouraging the establishment of new energy efficient ships and dismantling high energy consuming ships, and enhance the initiative of enterprises and individuals engaged in shipping energy conservation and emission reduction in the shipping industry.

Institutional factors: affecting the energy efficiency of waterway transportation, including the relevant standards and economic incentives for marine transport energy conservation.

The government departments of the State shall provide policy support for energy conservation and emission reduction of ships, promote the R \& D and application of energy save technologies, and issue various specifications and standards to ensure the practical application of energy save technologies.

\section{A. Improve Standards}

Improve standards, policies and regulations of energy save system, through the establishment of a new ship energy save design specification, evaluation system and technical standards, regulations to be invested ship operation market, divided into different types of ships and shipping areas, including second-hand ship shipbuilding, from the international market and to purchase foreign ships bareboat lease conditions, recommended fuel consumption limits and $\mathrm{CO} 2$ emission limits, the establishment of the operation of the ship market access standard.

In 2012, the operating ship fuel consumption limits and methods of verification and the operating ship CO2 emission limits and verification methods were published. Two measures recommended fuel consumption limits and CO2 emission limits (with different types of ships and shipping areas), emission index calculation and verification methods, measures for domestic ships, with diesel engines as the main propulsion, 400 gross tons and above the dry bulk ships, container ships and oil ship. Multi-purpose ships are carried out in reference to dry bulk carriers; they are not applicable to ships propelled by diesel electric propulsion, turbine propulsion and hybrid propulsion systems.

\section{B. Formulate Economic Incentive Policies}

Establish energy save performance evaluation and assessment system, formulate policies to encourage and encourage energy conservation and emission reduction, and form a long-term energy save mechanism to ensure the development of a resource-saving and environment-friendly shipping. Support for enterprises and institutions to carry out highway waterway transportation, energy save and emission reduction work, support and promote the development and application of the promotion and application of energy save and emission reduction of transportation industry new mechanism, new technology, new technology and new products.

\section{ENTERPRISE BREAKTHROUGH}

Shipping enterprises should face the high cost caused by the fuel price, and also face the restrictions of international conventions on the emission of international ships. How to save fuel consumption, reduce costs and control emissions to meet the requirements can be considered from three aspects of technology, structure and management.

Technical energy save emission reduction measures: through line optimization to reduce hydrostatic resistance, improve the efficiency and reduce the wave resistance. By increasing the use of high-strength steel or steel grade, optimize the design, reduce the structure, pipe and equipment weight, etc., to increase the carrying capacity of the ship.

Structural energy save and emission reduction measures: optimize the energy consumption structure of ships, use clean energy, including the application of liquefied natural gas (LNG) and biomass diesel power fuels, use solar energy lighting to generate electricity. Tonnage fleet structure optimization, large scale, standardization of ship development and technical standards to adapt to the channel, under the premise of ensuring safety, improve the economy, environmental protection, energy save and advanced maximum. Eliminate the old and inefficient carriers with high energy consumption and low efficiency, and minimize the energy consumption and emission of ships.

Management mode: energy save emission reduction measures of energy save and emission reduction management for advanced science, improve the ship loading rate by fleet planning, route optimization shorten the route voyage, strengthen ship economical speed management, the application of oil saving best speed.

Technological progress and economic development will promote the gradual improvement of technical standards for marine energy conservation and emission reduction, and make it more reasonable to restrict the selection of indicators. Collaborative IMO, our government, owner, industry management institutions and research institutions and Training Association and the power of the parties, to promote the progress and development of the ship energy save standards, believe that shipping will become greener.

\section{CONCLUSIONS}

To sum up, the paths of energy save and emission reduction of ships is determined by comprehensive factors of technology, structure, management and system. The current energy shortage and climate and environment deterioration have been an important topic of concern to all mankind. It is worthwhile to consider how to improve the efficiency of energy utilization, reduce the pollutant emissions of ships, make good use of the existing resources and energy, and promote the sustainable development of marine transportation. From the aspect of technology, research and promotion of energy save emission reduction, new type of marine energy save new technologies and new products using new technology to achieve energy save and emission reduction; 
from the aspect of structure, the inland and maritime fleet capacity, ship structure adjustment of energy consumption, the use of macro planning to achieve energy save and emission reduction; from the management, improve the operation level of energy save management of ship transportation organization management and ship use management means to achieve energy save and emission reduction; from the system, the establishment of ship energy save regulations system and standards, making the ship energy save economic policies to encourage the utilization system means to achieve energy save and emission reduction.

\section{REFERENCES}

[1] Guo Chunyu. Research and development of marine hydrodynamic compounded energy-saving. Ship Science and Technology, 36(04), 1-10. 2014

[2] Yang Zilong. Development Tendency of Marine Diesel Engine's Technology on Energy Saving and Emission Reduction. Diesel Engine, 35(03), 21-24. 2013

[3] Ye Hongling. Supply-side structural reforms to promote and accelerate the healthy development of port and shipping. CHINA WATER TRANSPORT, 510(05), 28. (2016)

[4] Yang Xiaodong. Discussion on China' s current status and measures to reduce emissions from ships PM2.5. Journal of Transport Management Institute Ministry of Transport, 70(05), 14-16. 2013

[5] Zhou Shuhui. Prospect of LNG application to inland water transportation in china. Natural gas industry, 232(02), 81-89. 2013

[6] Yan Xin ping. Progress Review of New Energy Application in Ship. SHIP \&OCEAN ENGINEERING, 39(05), 111-115. 2010

[7] Meisam Ahmadi Ghadikolaei. Study of Performance and Emissions of Marine Engines Fueled with Liquefied Natural Gas (LNG).2016 AMEC , Hong Kong, 1-6.2016

[8] ZHU Jianhua. Countermeasures for greenhouse gas emission reduction in China. 2009 Annual Meeting of China Environmental Science Society, CHINA, 1-3. 2009

[9] Zhang Peilin. Study on Energy Conservation and Its Method of Inland River Shipping Enterprises. 1994 Proceedings of Wuhan Institute of Navigation, WUHAN, CHINA, 1-3. 1994)

[10] Xu Yongfa. Research on Marine Power Management System (PMS). NAVIGATION OF CHINA, 28(03), 78-80. 2005.

[11] Qi Kunyuan. Discussion on Low-Carbon Ship Management. Western china communication Science \& Technology, 39(10), 90-91. 2010.

[12] Xing Hui. Method to Estimate Exhaust Emissions from Sea-Going Ships According to Operating Data. NAVIGATION OF CHINA, 108(03), 93-98. 2016.

[13] Peng Chuan Sheng. China's operating ship $\mathrm{CO}_{2}$ emission limits and verification methods. Navigation Technology, 199(01), 67-69. 2013.

[14] Peng ChuanSheng. Establishment and implementation of fuel consumption and $\mathrm{CO}_{2}$ emission limit for operating ships. Water transport management, 325 (11), 9-12. 2012.

[15] Peng ChuanSheng. Inland demonstration of energy-efficient ship energy efficiency analysis. Water transport management, 36 (06), 5-6+19. 2014

[16] Peng ChuanSheng. Chinese operation of ships fuel consumption limit market access standards and their implementation methods. Water transport management, 43 (11), 7-11. 2011.

[17] Xie Xie. On the Construction of Water Energy Monitoring System. Energy Conservation and Environmental Protection, 33 (03), 2-4+13. 2011.

[18] Li Jianli. Comparative Advantages of Waterway Transport in the Background of Low - carbon Economy. Water transport management, 37 (03), 14-16+19. 2010.

[19] Li Biying. The Status Quo of Energy Saving and Emission Reduction in Shipping Industry and Its Approach to Low-Carbon Development. JOURNAL OF ENGINEERING STUDIES, 23 (03), 260-269. 2012.
[20] Chen Aiming. On the shipping enterprises "energy-saving emission reduction" work thinking. China Water Transport, 23 (03), 63-64. 2013.

[21] Li Jiawei. Energy saving emission reduction in the use of shipping companies and thinking. Manager' Journal, 27 (03), 92-93. 2017.

[22] Wei Hongbin. From the perspective of ship operations to improve the efficiency of the ship options. China Water Transport, 37 (10), 58-59. 2016.

[23] Wei Hongbin. Improving the energy efficiency of the ship. Pearl River Water Transport, 35 (12), 86-87. 2015. 